\title{
Karakteristik Fisikokimia Serbuk Kolang Kaling (Arenga pinnata Merr) Berdasarkan Variasi Perendaman
}

\section{Physicochemical Characteristics of Kolang Kaling (Arenga pinnata Merr) Based on Seed Variation}

\author{
Tiana Fitrilia'1a, Dwi Aryanti Nur'utami'1, Resti Shapariah'1 \\ ${ }^{1}$ Jurusan Teknologi Pangan dan Gizi, Fakultas Ilmu Pangan Halal, Universitas Djuanda Bogor, \\ 16720, Jl. Tol Ciawi No. 1, Kotak Pos 35 Ciawi, Bogor 16720. \\ aKorespondensi : Tiana Fitrilia, E-mail: tiana.fitrilia@unida.ac.id
}

(Diterima oleh Dewan Redaksi : 25 - 04 - 2019)

(Dipublikasikan oleh Dewan Redaksi : 30 - 04 - 2019)

\begin{abstract}
Kolang kaling is an endosperm from palm fruit seeds obtained by boiling. This study aims to obtain kolang kaling in powder form and determine the physicochemical characteristics of the produced kolang kaling powder. Fresh kolang kaling was given an immersion treatment with clean water and a mixture of water: rice flour for 24, 48 and 72 hours. Powder making was done by drying using a microwave oven. Kolang kaling powder was analyzed physically and chemically consisting of yield, color and proximate. The results showed that the yield obtained of $6.97-8.89 \%$, the color of kolang kaling powder had a brightness value (L) of 71.87 - 83.09, a value of 7.05 - 7.69 and b value of 8.67 - 16.13. Proximate analysis of kolang kaling powder from immersion with water and mixture of water : rice flour for 24, 48 and 72 hours produced the highest carbohydrate content compared to water, ash, fat and protein content, namely $72.29-85.08 \%$.
\end{abstract}

Keywords: Kolang kaling, immersion, microwave oven

\begin{abstract}
ABSTRAK
Kolang kaling merupakan endosperma dari biji buah aren yang diperoleh dengan cara perebusan. Penelitian ini bertujuan mendapatkan kolang kaling dalam bentuk serbuk dan mengetahui karakteristik fisikokimia serbuk kolang kaling yang dihasilkan. Kolang kaling segar diberi perlakuan perendaman dengan air bersih dan campuran air:tepung beras selama 24, 48 dan 72 jam. Pembuatan serbuk dilakukan dengan cara pengeringan menggunakan oven gelombang mikro. Serbuk kolang kaling dianalisis secara fisik dan kimia yang terdiri atas rendemen, warna dan proksimat. Hasil penelitian menunjukkan bahwa rendemen sampel uji berkisar 6,97 - 8,89\%, warna serbuk kolang kaling memiliki nilai kecerahan (L) sebesar 71,87 - 83,09, nilai a sebesar 7,05 - 7,69 dan nilai b sebesar 8,67 16,13 . Analisis proksimat serbuk kolang kaling hasil perendaman dengan air dan campuran air:tepung beras selama 24, 48 dan 72 jam menghasilkan nilai karbohidrat paling tinggi dibandingan dengan kadar air, abu, lemak dan protein yaitu berkisar 72,29-85,08\%.
\end{abstract}

Kata kunci: Kolang kaling, perendaman, oven gelombang mikro

Fitrilia, Tiana, Dwi Aryanti Nur'utami, Resti Shapariah. 2019. Karakteristik Fisikokimia Serbuk Kolang Kaling (Arenga pinnata Merr) Berdasarkan Variasi Perendaman. Jurnal Agroindustri Halal 5(1): 104 112 


\section{PENDAHULUAN}

Indonesia merupakan negara yang kaya akan keanekaragaman hayati. Salah satu keanekaragaman tanaman di Indoneisa adalah tanaman aren. Tanaman Aren (Arenga pinnata Meer) merupakan tanaman yang memiliki nilai ekonomi tinggi dan dapat tumbuh tersebar hampir diseluruh Indonesia yang berada di garis lintang iklim tropis. Aren telah lama dibudidayakan di Indonesia dan telah diketahui manfaat ekonominya sejak dahulu kala (Mariati, 2013). Menurut Lempang (2012), hampir seluruh bagian tanaman ini dapat bermanfaat dan dapat digunakan untuk berbagai kebutuhan, mulai dari bagian fisik (akar, batang, daun, dan ijuk) maupun hasil produksinya (nira, pati/tepung, dan buah kolang-kaling).

Salah satu hasil dari aren adalah buahnya yang dapat diolah menjadi kolangkaling. Proses pengolahan buah aren menjadi kolang-kaling dapat mempengaruhi mutu dari kolang-kaling yang dihasilkan. Secara empiris, masyarakat biasanya melakukan perendaman sebelum kolangkaling dipasarkan, dengan tujuan agar kolang-kaling lebih bersih, kenyal dan mengembang. Kolang-kaling merupakan endosperm dari biji buah aren, memiliki tekstur yang kenyal, berwarna putih serta memiliki bentuk yang lonjong. Kolang kaling dapat ditemukan dengan mudah di pasar tradisional karena tidak bersifat musiman. Kolang-kaling cukup diminati oleh masyarakat terutama pada bulan ramadhan. Namun, pemanfaatan kolang-kaling saat ini masih sangat terbatas (Sarmi et al. 2016). Biasanya hanya dikonsumsi sebagai manisan atau makanan penutup (Hussin et al. 2017). Padahal kolang-kaling memiliki kandungan kimia yang baik untuk kesehatan (Lempang, 2012). Kolang-kaling memiliki kadar air sebesar 93,6 \%, protein 2,344 \%, karbohidrat $56,57 \%$, serta serat kasar 10,52\% (Tarigan dan Kaban, 2009).

Tingginya kadar air pada kolangkaling menjadi isolat yang tepat untuk pertumbuhan mikroba. Oleh karena itu, dibutuhkan teknologi pengawetan yang dapat meningkatkan daya simpan dari kolang-kaling tersebut. Cara yang dapat dilakukan adalah membuat kolang-kaling menjadi bentuk serbuk melalui proses pengeringan. Pengeringan kolang-kaling dilakukan untuk menurunkan aktivitas air dengan cara menguapkan air dari bahan pangan. Aktivitas air yang rendah dapat mencegah resiko kerusakan bahan akibat aktivitas enzimatis dan biologi sehingga bahan pangan dapat dijaga kualitasnya selama proses penyimpanan.

Pengeringan merupakan aspek penting dalam pengolahan makanan dan merupakan teknik umum dalam pengawetan untuk menghasilkan bentuk baru produk yang diinginkan (Mechlouch et al. 2012). Berdasarkan latar belakang tersebut, perendaman menjadi salah satu faktor penting untuk mendapatkan mutu serbuk kolang-kaling. Oleh karena itu, perlu dilakukan penelitian mengenai variasi jenis dan waktu perendaman kolang-kaling untuk dijadikan serbuk.

Tujuan umum dari penelitian ini adalah mendapatkan kolang kaling dalam bentuk sediaan serbuk sebagai upaya pengawetan bahan pangan. Sementara tujuan khususnya adalah mengetahui karakterisitik serbuk kolang kaling yang dihasilkan.

\section{MATERI DAN METODE}

\section{Kolang Kaling}

Kolang-kaling merupakan salah satu hasil panen dari tanaman aren. Tanaman aren merupakan salah satu keluarga palma yang dapat tumbuh subur di wilayah tropis seperti Indonesia. Menurut Manambangtua et al. (2018), sebagian besar populasinya tumbuh secara liar dan tersebar secara alami, baik di dataran rendah, lereng, bukit, lembah maupun pegunungan. Tanaman aren berdiri tegak dan tinggi, berbatang bulat, berwarna hijau kecoklatan, serta bentuk daun menyirip (Sebayang, 2016). Kolang-kaling berwarna putih bening, mengkilat, bertekstur kenyal, dan lunak (Gambar 1). 


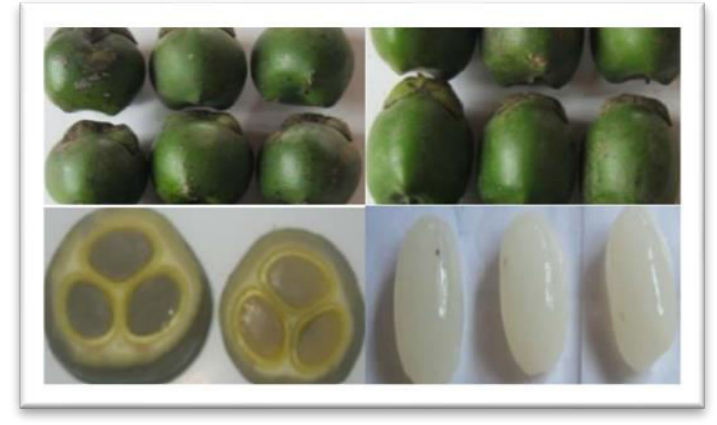

Gambar 1. Kolang kaling

Sumber : (Ferrita et al. 2015)

\section{Perendaman}

Perendaman merupakan salah satu proses yang dilakukan dalam pengolahan kolang-kaling (Irwanto dan Sahupala, 2015). Para pengrajin kolang-kaling biasanya melakukan perendaman kolang-kaling selama 3 hari hingga tercium aroma khas kolang-kaling. Perendaman yang dilakukan adalah dengan menggunakan air bersih atau larutan tepung beras. Air dapat membersihkan kotoran pada bahan pangan (Haris et al. 2013). Tujuan dari perendaman kolang-kaling adalah agar kolang-kaling lebih bersih dan putih, serta kolang-kaling lebih mengembang (Tamrin dan Prayitno, 2008).

\section{Serbuk Kolang Kaling}

Serbuk dapat dideskripsikan sebagai partikel halus yang merupakan hasil penghalusan dari zat-zat yang kering (Pulungan et al. 2004). Bentuk serbuk memiliki luas permukaan yang besar, sehingga akan mudah terlarut atau tercampur dibandingkan bentuk sediaan lainnya (Ansel, 2008). Pembuatan kolangkaling dalam bentuk serbuk selain bertujuan untuk memperpanjang daya simpan, juga agar memudahkan proses penyimpanan. Selain itu bahan pangan dalam bentuk serbuk akan menyederhanakan penggunaan. Menurut Napitupilu (2014), bahan pangan kering dalam bentuk serbuk dapat disimpan hingga berbulan-bulan dan lebih ringan dalam pengangkutan karena kadar airnya telah berkurang sehingga memudahkan dalam transportasi dan penanganannya.

\section{Bahan dan Alat}

Bahan yang digunakan adalah kolang kaling segar yang diperoleh dari daerah Cianjur, Jawa Barat, tepung beras, aquades, dan bahan-bahan yang digunakan untuk analisis. Sedangkan alat-alat yang digunakan adalah oven gelombang mikro, labu lemak, labu kjeldhal, soklet, tanur, oven, desikator, neraca analitik, chromameter dan peralatan gelas.

\section{Waktu dan Tempat Penelitian}

Penelitian dilaksanakan di Laboratoriun Sains Universitas Djuanda dan Laboratorium Pengolahan Pangan, Fakultas Ilmu Pangan Halal. Waktu Penelitian dimulai dari Februari sampai April 2018.

\section{Pembuatan Serbuk Kolang Kaling}

Kolang-kaling yang baru di kupas dilakukan perendaman dengan dua jenis perendaman yaitu air bersih dan campuran air : tepung beras (1 L : $1 \mathrm{~g}$ ). Perendaman dilakukan selama 24 jam, 48 jam, serta 72 jam.

Kolang-kaling yang telah direndam kemudian dilakukan pencucian menggunakan air mengalir dan disortasi berdasarkan ukuran yang sama, kemudian dilakukan pengirisan secara tipis, dikeringkan menggunakan oven gelombang mikro pada daya 70\% (600 watt) selama 30 menit. Produk yang telah kering dihaluskan dengan blender sehingga diperoleh serbuk kolang-kaling. Serbuk kolang-kaling kemudian dilakukan pengujian rendemen, warna, dan proksimat. Diagram alir pembuatan serbuk kolang kaling dapat dilihat pada Gambar 2. 


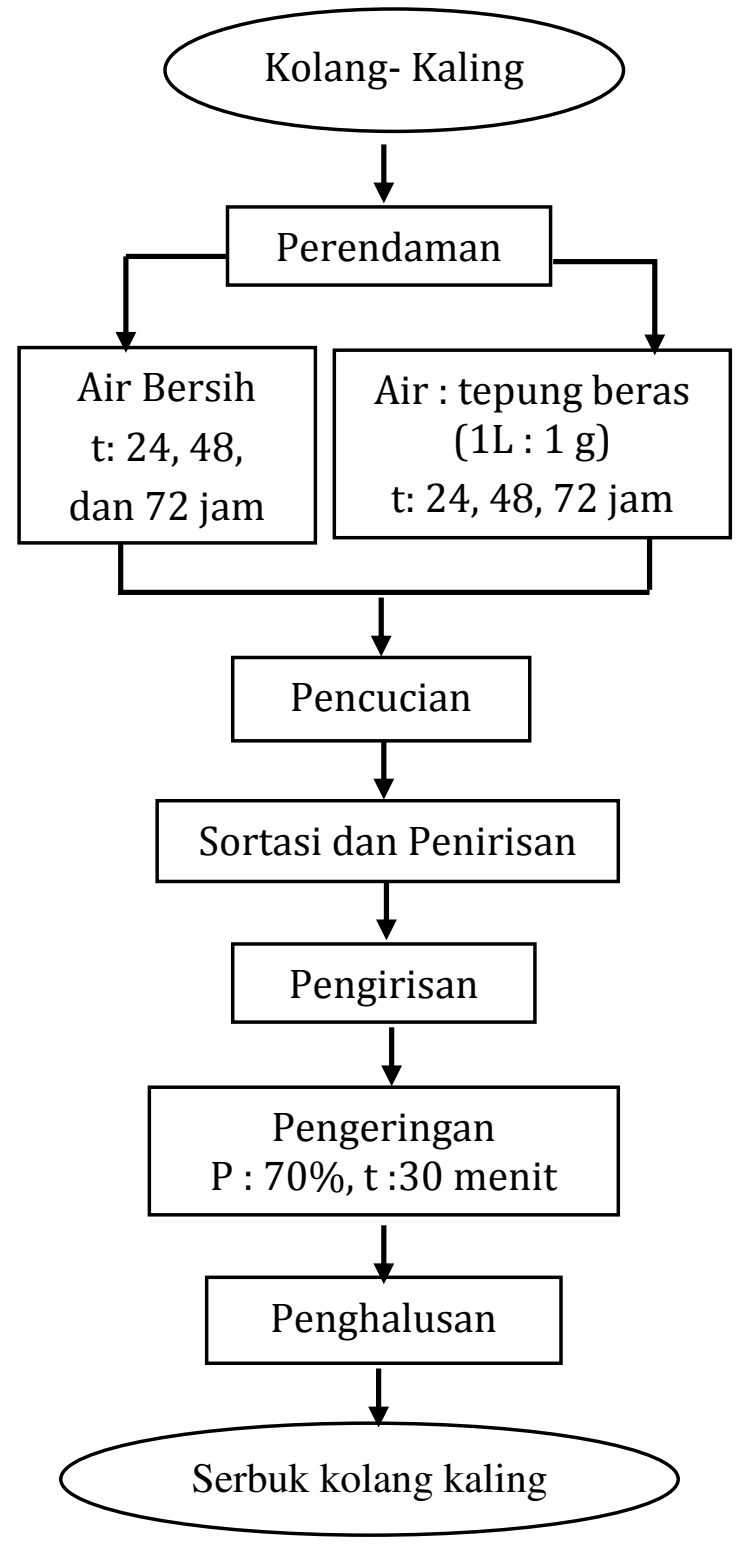

Gambar 2. Pembuatan serbuk kolang kaling

(Modifikasi Pratama, 2016)

HASIL DAN PEMBAHASAN

\section{Serbuk Kolang kaling}

Kolang kaling yang dijadikan serbuk merupakan kolang kaling yang memiliki tekstur agak keras. Menurut Torio et al. (2006), kolang kaling dapat diklasifikasikan berdasarkan tingkat kematangan buah arennya dimana kolang kaling yang memiliki tekstur agak keras merupakan kolang kaling setengah matang dengan kisaran umur 16-18 bulan. Sebelum proses pengeringan, kolang kaling dilakukan perendaman dengan air bersih dan air : tepung beras. Perendaman bertujuan mendapatkan tekstur kolang kaling yang lebih kenyal. Selain itu, menurut Dameswari (2017), perendaman kolang kaling menggunakan air dapat mencegah perubahan warna akibat kontak langsung dengan udara. Adapun karakteristik serbuk kolang kaling tanpa perlakuan perendaman dapat dilihat pada Tabel 1.

Tabel 1. Karakteristik Serbuk Kolang Kaling Tanpa Perendaman

\begin{tabular}{llc}
\hline No & \multicolumn{1}{c}{ Parameter } & Nilai \\
\hline 1 & Rendemen (\%) & 10.64 \\
2 & Warna & \\
& L $^{*}$ & 78.07 \\
& $\mathrm{a}^{*}$ & 8.55 \\
& $\mathrm{~b}^{*}$ & 12,43 \\
3 & Air (\%) & 11.04 \\
4 & Abu (\%) & 1.02 \\
5 & Lemak (\%) & 2.63 \\
6 & Protein (\%) & 1.27 \\
7 & Karbohidrat (\%) & 84.04 \\
\hline
\end{tabular}

Berdasarkan Tabel 1, serbuk kolang kaling tanpa perlakuan perendaman memiliki rendemen 10,64\%. Rendemen tersebut diperoleh dari hasil perbandingan kolang kaling segar dengan kolang kaling yang telah dibuat serbuk.

Analisis warna terhadap serbuk kolang kaling dilakukan menggunakan alat Chromamater. Nilai L menyatakan kecerahan yang memiliki nilai minimun 0 (hitam) dan maksimum 100 (putih), nilai a merupakan warna kromatik campuran warna hijau-merah dengan nilai ta berwarna merah dan -a berwarna hijau, sementara nilai b merupakan warna kromatik campuran biru-kuning dengan $+b$ berwarna kuning dan -b berwarna biru (HunterLab, 2008). Hasil analisis menunjukkan bahwa serbuk kolang kaling tanpa perendaman memiliki nilai tingkat kecerahan (L) cenderung bewarna putih, 
nilai a (8.55) cenderung berwarna kemerahan dan nilai b (12.43) cenderung berwarna kekuningan.

Berdasarkan analisis proksimat yang terdiri atas kadar air, abu, protein, lemak dan karbohidrat, bahwa serbuk kolang kaling tanpa perendaman mengandung komponen karbohidrat lebih banyak dibandingkan komponen lainnya. Hal ini menunjukkan bahwa karbohidrat merupakan penyumbang kalori tertinggi pada serbuk kolang kaling yang tidak diberi perlakuan perendaman.

\section{Karakteristik Fisikokimia Serbuk Kolang Kaling berdasarkan Variasi Perendaman}

Serbuk kolang kaling dengan perlakuan perendaman dianalisis secara fisik dan kimia. Hasil analisis secara fisik terdiri atas rendemen (Tabel 2) dan warna (Tabel 3).
Tabel 2. Rendemen Serbuk Kolang kaling

\begin{tabular}{lc}
\hline Sampel & $\begin{array}{c}\text { Rendemen } \\
\text { (\%) }\end{array}$ \\
\hline Air Bersih (24 Jam) & 8.89 \\
Air Bersih (48 Jam) & 6.97 \\
Air Bersih (72 Jam) & 8.70 \\
Air:Tepung Beras (24 Jam) & 8.26 \\
Air:Tepung Beras (48 Jam) & 7.69 \\
Air:Tepung Beras (72 Jam) & 7.90 \\
\hline
\end{tabular}

Berdasarkan Tabel 2, nilai rendemen sampel uji berkisar antara 6.97 - 8.89\%. Nilai rendemen yang dihasilkan masih tergolong kecil. Hal ini diduga karena komponen utama kolang kaling adalah air yang dapat menguap pada proses pengeringan. Menurut Yenrina et al. (2016), kadar air kolang kaling segar adalah 95,97 $\%$.

Tabel 3. Warna Serbuk Kolang Kaling

\begin{tabular}{lccc}
\hline Sampel & $\mathbf{L}^{*}$ & $\mathbf{a}^{*}$ & $\mathbf{b}^{*}$ \\
\hline Air Bersih (24 Jam) & $81.05 \pm 0.191$ & $7.27 \pm 0.021$ & $9.75 \pm 0.651$ \\
Air Bersih (48 Jam) & $77.57 \pm 1.782$ & $7.10 \pm 0.361$ & $13.01 \pm 1.131$ \\
Air Bersih (72 Jam) & $71.87 \pm 1.541$ & $7.05 \pm 0.240$ & $16.13 \pm 0.042$ \\
Air : Tepung Beras (24 Jam) & $83.09 \pm 0.325$ & $7.69 \pm 0.191$ & $8.67 \pm 0.071$ \\
Air : Tepung Beras (48 Jam) & $78.82 \pm 0.742$ & $7.67 \pm 0.021$ & $11.93 \pm 0.472$ \\
Air : Tepung Beras (72 Jam) & $74.10 \pm 3.825$ & $7.07 \pm 1.407$ & $14.32 \pm 0.735$ \\
\hline
\end{tabular}

Warna merupakan salah satu parameter penentu kualitas mutu sensori suatu produk. Hasil analisis warna pada Tabel 3 menunjukkan bahwa serbuk kolang kaling hasil perendaman dengan air bersih dan air : tepung beras selama 24, 48 dan 72 jam memberikan nilai kecerahan berkisar antara 71.87 - 83.09 yang cenderung berwarna putih. Nilai a berkisar antara 7.05 - 7.69 yang mengarah ke warna merah dan nilai b berkisar antara 8.67 - 16.13 yang mengarah ke warna kuning. Menurut Pratama (2016), warna kekuningan pada kolang kaling disebabkan karena adanya proses pengeringan.

Selain analisis fisik, serbuk kolang kaling yang diperoleh dari perlakuan perendaman di analisis juga secara kimia berupa analisis proksimat yang terdiri atas kadar air, kadar abu, kadar lemak, kadar protein dan karbohidrat. Hasil analisis proksimat dapat dilihat pada Gambar 3-7.

\section{Kadar Air}

Kadar air merupakan persentase kandungan air yang ada dalam suatu bahan dan dapat dinyatakan berdasarkan berat 
basah atau berat kering. Penentuan kadar air biasanya berkaitan dengan indeks kestabilan terutama masa simpan (Landeng et al. 2017). Kadar air yang tinggi dapat menyebabkan suatu bahan cepat mengalami kerusakan. Kadar air serbuk kolang kaling berdasarkan variasi dan waktu perendaman dapat dilihat pada Gambar 3.

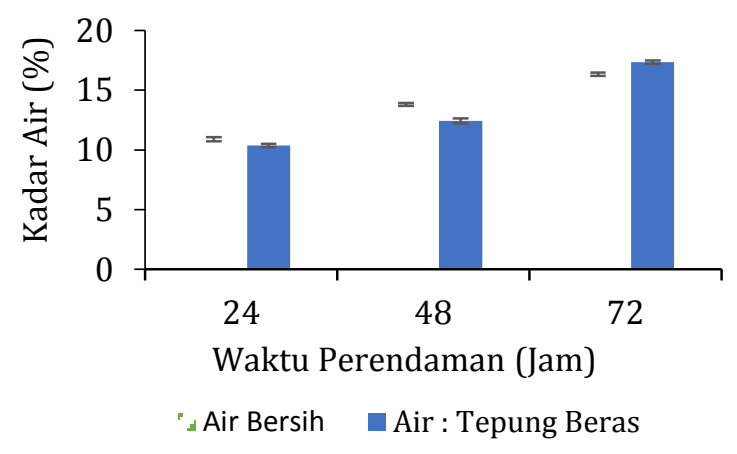

Gambar 3. Kadar air serbuk kolang kaling

Berdasarkan Gambar 3, kadar air serbuk kolang kaling dengan dua variasi perendaman cenderung mengalami kenaikan sejalan dengan lamanya waktu perendaman. Serbuk kolang kaling hasil perendaman dengan air bersih memiliki kadar air berkisar antara $10.91 \%-16.33 \%$. Sementara kadar air serbuk kolang kaling hasil perendaman dengan air : tepung beras berkisar antara $10.36 \%-17.35 \%$. Tingginya kadar air serbuk kolang kaling disebabkan oleh sifat kolang kaling yang mudah menyerap air. Menurut Hussin et al. (2017), kolang kaling mengandung senyawa hidrokoloid yang mampu memerangkap sejumlah air melalui rantai dan cabang yang ada pada struktur molekulnya.

\section{Kadar Abu}

Abu merupakan residu anorganik hasil oksidasi senyawa organik bahan pangan. Berdasarkan Gambar 4, kadar abu serbuk kolang kaling hasil perendaman dengan air bersih dan waktu perendaman 24, 48 dan 72 jam secara berturut-turut memiliki nilai 0.62 $\%, 0.70 \%$ dan $0.66 \%$. Sementara kadar abu serbuk kolang kaling hasil perendaman dengan air : tepung beras dan waktu perendaman 24, 48 dan 72 jam secara berturut-turut memiliki nilai $0.76 \%, 0.64 \%$ dan $0.70 \%$.

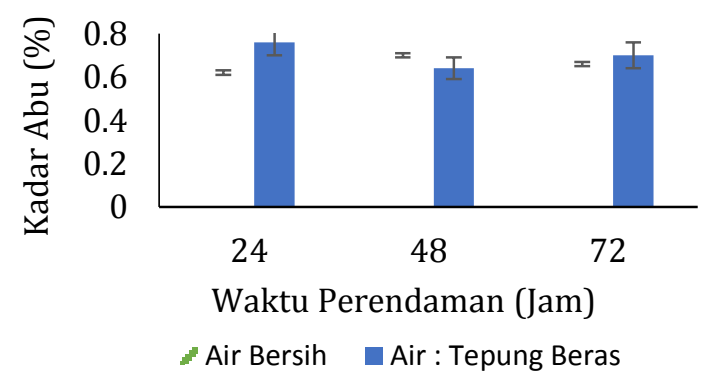

Gambar 4. Kadar abu serbuk kolang kaling

Sesuai dengan penelitian Pratama (2016) tentang karateristik serbuk kolang kaling berdasarkan jenis pengeringan dimana serbuk kolang kaling yang dikeringkan dengan oven gelombang mikro memiliki kadar abu 0.73\%. Menurut Sayuti et al. (2017), kadar abu menunjukkan kandungan mineral yang terdapat pada suatu bahan.

\section{Kadar Lemak}

Lemak termasuk kedalam golongan lipid yang memiliki konsistensi padat pada suhu ruang. Penentuan kadar lemak sampel uji menggunakan metode soxhlet yaitu ekstraksi lemak menggunakan pelarut organik, kemudian pelarutnya dievaporasi dan kadar lemak yang diperoleh dilakukan penimbangan.

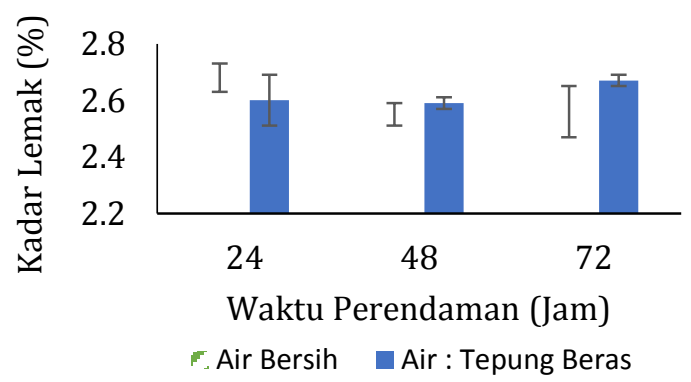

Gambar 5. Kadar lemak serbuk kolang kaling

Berdasarkan Gambar 5, kadar lemak serbuk kolang kaling hasil perendaman dengan air bersih dan waktu perendaman 
24, 48 dan 72 jam secara berturut-turut memiliki nilai $2.68 \%, 2.55 \%$ dan $2.56 \%$. Sementara kadar lemak serbuk kolang kaling hasil perendaman dengan air : tepung beras dan waktu perendaman 24, 48 dan 72 jam secara berturut-turut memiliki nilai $2.60 \%$, 2.59 dan 2.67\%. Torio et al. (2006) melakukan analisis kadar lemak bubur kolang kaling berdasarkan tingkat kematangan buah dimana kolang kaling dengan tingkat kematangan sedang yang berasal dari filipina memiliki kadar abu $0.42 \%$. Perbedaan nilai kadar abu menunjukkan bahwa jenis perlakuan dan asal spesies menentukan jumlah kadar lemak yang dihasilkan.

\section{Kadar Protein}

Kadar protein sampel diperoleh dengan menggunakan metode Kjeldahl yaitu berdasarkan penentuan jumlah nitrogen yang ada pada suatu bahan.

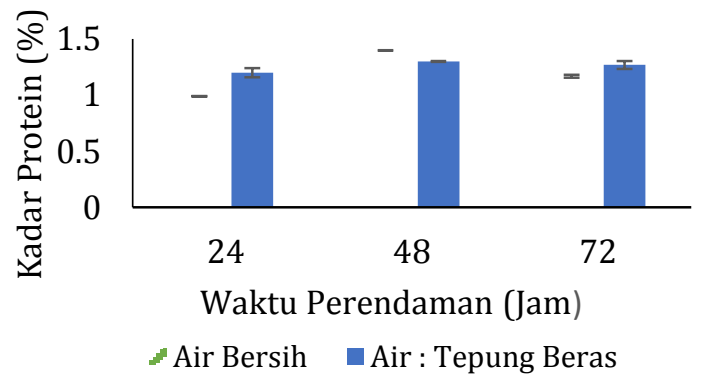

Gambar 6. Kadar protein serbuk kolang kaling

Berdasarkan Gambar 6, kadar protein serbuk kolang kaling hasil perendaman dengan air bersih dan waktu perendaman 24, 48 dan 72 jam secara berturut-turut memiliki nilai $0.99 \%, 1.40 \%$ dan $1.17 \%$ Sementara kadar protein serbuk kolang kaling hasil perendaman dengan air : tepung beras dan waktu perendaman 24, 48 dan 72 jam secara berturut-turut memiliki nilai $1.20 \%, 1.30 \%$ dan $1.27 \%$. Kadar protein jus kolang kaling yang dianalisis oleh Arsad et al. (2017) dengan kondisi rasio air dan kolang kaling (1:3) serta pasteurisasi pada suhu $85^{\circ} \mathrm{C}$ selama 5 menit memiliki nilai 2.83\%. Menurut Pratama (2016), pengeringan kolang kaling yang dibuat serbuk dapat menurunkan kadar protein kolang kaling tersebut karena terjadi reaksi Maillard dan denaturasi protein. Oleh karena itu, metode pemberian panas pada suatu bahan pangan dapat menentukan jumlah kadar protein yang dihasilkan.

\section{Kadar Karbohidrat}

Kadar karbohidrat diperoleh secara by difference dengan melibatkan komponen lain yaitu kadar air, abu, lemak dan protein.

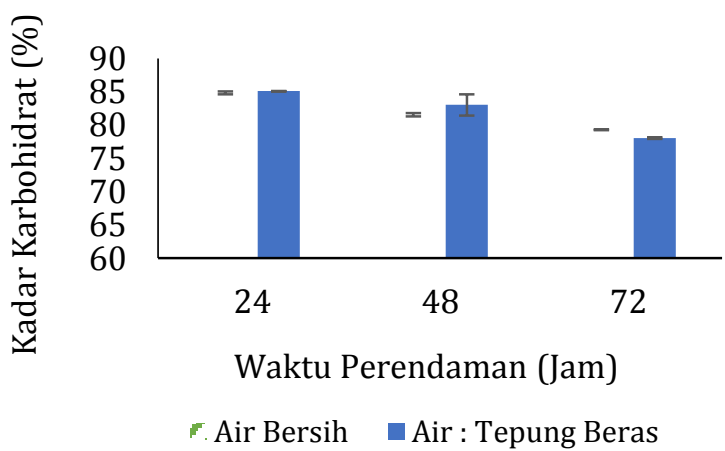

Gambar 7. Kadar karbohidrat serbuk kolang kaling

Berdasarkan Gambar 7, kadar karbohidrat serbuk kolang kaling hasil perendaman dengan air besih dan waktu perendaman 24, 48 dan 72 jam secara berturut-turut memiliki nilai $84,82 \%$, 81,54\% dan 79.29\%. Sementara kadar karbohidrat serbuk kolang kaling hasil perendaman dengan air : tepung beras dan waktu perendaman 24, 48 dan 72 jam secara berturut-turut memiliki nilai $85.08 \%$, 83.02\% dan 78.03\%. Hasil analisis yang dilakukan oleh Pratama (2016) terhadap serbuk kolang kaling hasil perendaman dengan air bersih selama 3 hari menggunakan oven gelombang mikro menghasilkan kadar karbohidrat sebesar 87.01\%.

\section{KESIMPULAN}

Kolang kaling yang direndam dengan air bersih dan air:tepung beras selama 24, 48 dan 72 jam dapat dibuat menjadi sediaan 
serbuk dengan menggunakan oven gelombang mikro. Serbuk kolang kaling yang dihasilkan memiliki nilai rendemen berkisar 6.97 - 8.89\% dan warna dengan nilai kecerahan (L) cenderung berwarna putih, nilai a mengarah ke warna merah dan nilai $b$ mengarah ke warna kuning. Hasil uji proksimat menunjukkan bahwa karbohidrat memiliki nilai paling tinggi dibandingkan dengan komponen lain yaitu sebesar 72.29 85.08\%.

\section{DAFTAR PUSTAKA}

Ansel, H. C. 2008. Pengantar bentuk sediaan farmasi. Ed ke-4. UI Press. Jakarta

Arsad P, Sukor R, Wan I.W.Z, Mustapha N.A, Meor H.A.S. 2015. Effect of enzymatic treatment on physicochemical properties of sugar palm fruit juice. 5(5) : 308-312.

Dameswari A.H. Darmawati E. Nugroho L.P.E. 2017. Kombinasi teknologi kemasan dan bahan tambahan untuk mempertahankan mutu kolang kaling. jTEP Jurnal Keteknikan Pertanian. 5(3): 201-208.

Ferita I, Tawarati, Syarif Z. 2015. Identifikasi dan Karakterisasi Tanaman Enau (Arenga pinnata) di Kabupaten Gayo Lues. Prosiding Seminar Nasional Masyarakat Biodiversitas Indonesia Vol.1(1):31-37.

Haris, R., Santosa, G.W., Ridlo, A. 2013. Pengaruh perendaman air kapur terhadap kadar sulfat dan kekuatan gel karaginan Rumput Laut Kappaphycus alvarezi. 2(2): 1-10.

HunterLab. 2008. Hunter L, a, b color scale. 8(9) : 1-4.

Hussin A.S.M, Sapawi C.W.N.S.C.W, Anzian A, Ramli H.B. 2017. Aqueous extraction, purification and characterization of Galactomannans from Aren Sugar Palm (Arenga pinnata) Fruits. International Journal on Advanced Science Engineering Information Technology. 7(4):1148-1154

Irwanto., Sahupala, A. 2015. Pemanfaatan Buah Aren (Arenga Pinnata Merr) untuk peningkatan pendapatan petani Desa Hatusua, Kabupaten Seram Barat. Journal of Community Service Vol. 4(2): 76-83.

Lempang, M. 2012. Pohon aren dan Manfaat produksinya. Info Teknis EBONI Vol. 9(1): 37-54.

Landeng P.J, Suryanto E, Momuat L.I. 2017. Komposisi proksimat dan potensi antioksidan dari biji jagung Manado kuning (Zea mays L.). Chem. Prog. 10 (1).

Manambangtua, A.p., Hutapea, R. T. P., Wungkana, J. 2018. Analisis usaha tani Aren (Arrenga Pinnata Merr) di Kota Tomohon, Sulawesi Utara. Jurnal Sosial Ekonomi Vol. 14(1): 85-92.

Mariati, R. 2013. Potensi produksi dan prospek pengembangan tanaman Aren (Arenga pinnata MERR) di Kalimantan Timur. Jurnal AGRIFOR Vol. 12(2) : 196205.

Mechlouch, R.F. W. Elfalleh., M. Ziadi., H. Hannachi., M. Chwikhi., A.B. Aoun., I. Elakesh, dan F. Cheour. 2012. Effect of Drying Methods on the physico-chemical properties of tomato variety rio grande. Int. J. F. Eng. 8: Iss. 2, Art.4. DOI : 10.1515/1556-37582678.

Napitupulu, F. I. R. 2014. Metode Pengeringan Andaliman (Zanthoxylum acanthodium DC.) untuk memperoleh mutu sensori aroma dan sensasi trigemial yang optimum [skripsi]. Fakultas Teknologi Pertanian. Institut Pertanian Bogor. Bogor.

Pratama, E.R. 2016. Pengoptimuman pengeringan terhadap aktivitas antioksidan, kadar galaktomanan, dan komposisi kimia Kolang-Kaling [skripsi]. Fakultas Matematika dan Ilmu Pengetahuan Alam. Institut Pertanian Bogor. Bogor.

Pulungan, M.H., Suprayogi, Yudha B. 2004. Effervescent tanaman obat. Trubus Agrisarana. Surabaya.

Sayuti K, Yenrina R, Anggraini T. 2012. Characteristics of "Kolang-Kaling" (Sugar Palm Fruit Jam) with added natural 
colorants. Pakistan Journal of Nutrition.

16(2):69-76. ISSN 1680-

5194.doi:10.3923/pjn.2017.69.76

Sebayang, L. 2016. Keragaan eksisting tanaman Aren (Arenga pinnata Merr) di Sumatera Utara (Peluang dan Potensi Pengembangannya). Jurnal Pertanian Tropik Vol. 3(2): 133-138.

Tamrin., Prayitno, L. 2008. Pengaruh lama perebusan dan perendaman terhadap kadar air dan tingkat kelunakan KolangKaling. Di Dalam Prosiding Seminar Nasional Sains dan Teknologi; 17-18 November 2008. hlm 44-49.

Tarigan, B. J. 2012. Edible film adaptationantioxidatie and antimicrobial by Galactomanan Extract on Biji Aren (Arenga Pinata) and Daun Kemangi (Ocium basilium L.) [disertasi]. Universitas Sumatera Utara. Sumatera Utara.

Torio, O.A.M., Saez, J., Merca, E.f. 2006 Physicochemical characterization of Galaktomanan from Sugar Palm (Arenga saccharifera Labill.) endosperm at different stage of nut maturity. Philipine Journal Science Vol. 135(1): 19-30.

Sarmi., Ratnani, R.D., Hartati, I. 2016. Isolasi senyawa galaktomanan Buah Aren (Arenga Pinnata) menggunakan beberapa jenis abu. Momentum Vol. 12(1) : 21-25.

Yenrina R, Nazir N, Ulfa P.2016. Characteristics of jelly powder of sugar palm fruit (Arenga pinnata, Merr) and seaweed (Eucheumacottonii). International Journal of Advanced Research. 4(2). 916-921. Doi:10.21474/IJAR01. 